Vlatko Kastratović $^{1 *}$, Slađana Krivokapić ${ }^{1}$, Dijana Đurović ${ }^{2}$

${ }^{1}$ University of Montenegro, Faculty of Natural Sciences and

Mathematics, Podgorica, Montenegro, ${ }^{2}$ Institute of Public Health of Montenegro, Podgorica, Montenegro
Scientific paper

ISSN 0351-9465, E-ISSN 2466-2585

UDC: $546.881+553.26(497.16$

Skadarsko jezero)

doi: 10.5937/zasmat2001031K

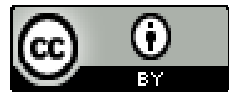

Zastita Materijala 61 (1)

$31-40$ (2020)

\title{
Vanadium uptake, translocation and bioaccumulation in ecosystem of Skadar Lake, Montenegro
}

\begin{abstract}
Lake Skadar is a highly vulnerable ecosystem affected by various types of anthropogenic pressures. In the last few years, interest in vanadium (V) has increased due to several negative effects on the environment. Our research aims to find the $V$ content per fractions of sediments, and estimate bioavailability, including by analyzing content ratios in the sediment, in water and macrophytes and plant tissue distribution. Low content of vanadium was recorded in the water. In the sediment of Skadar Lake, values were found in the range of 18.1 to $49.5 \mathrm{mgkg}^{-1}$. The largest amounts of $V\left(11.8 \mathrm{mgkg}^{-1}\right)$ are found in mineral crystalline lattices (residual fraction), so $V$ is substantially immobilized in the sediment of the lake. Based on the calculated geochemical parameters, it can be concluded that the sediment of Skadar Lake is not contaminated with $V$ and it is under the low risk category at all investigated locations. In the tissues of the examined macrophytes, the mean value of $V$ content, in relation to the location and sampling time, is in the range 0.05-8.15 $\mathrm{mgkg}^{-1}$ of the dry part of the plant. The studied macrophytes showed a low bioaccumulation capacity for $V$. A different seasonal trend of concentration of $V$ in macrophytes was recorded. And the translocation ability between individual parts of the plant is different and depends on the type of macrophytes.
\end{abstract}

Keywords: Skadar Lake, sediment, macrophytes, vanadium, bioindicator.

\section{INTRODUCTION}

Lacustrine systems are complex water systems in terms of the transport and interaction with chemical substances due to the numerous and complex processes that occur in these ecosystems [1].

The resulting quality arises as a result of many factors: starting from geochemical origin, its geographical position and the corresponding climate and hydrological characteristics, the morphometry of the lake and the characteristics of the catchment area, to the physical, chemical and biological factors in the water system itself $[1,2]$.

However, recent anthropogenic impacts have a decisive influence on the changes in the dynamics of any lake ecosystem, so rapid ecosystem changes are increasingly becoming a trend.

${ }^{*}$ Corresponding author: Vlatko Kastratović

E-mail: vlatkok@ucg.ac.me

Paper received: 07. 09. 2019.

Paper accepted: 22. 11. 2019.

Paper is available on the website:

www.idk.org.rs/journal
Skadar Lake is a highly vulnerable ecosystem affected by various types of anthropogenic pressures: an increasing number of tourists; land drainage from surrounding agricultural holdings; more intensive fishing; poor sewage system and the problem of communal water; relative proximity to stationed industrial facilities and airports increased land and water traffic due to the increasing urbanization of the lake.

In the past few years, interest for presence of vanadium (and some other toxic elements) has increased due to the negative effect on the environment [3]. Vanadium is widely dispersed in the environment in several ways including the leaching for rocks, the combustion of coal or petroleum products, the contamination from the use of fertilizers, and residual slags from the steel industry. As a result, $\mathrm{V}$ has been increasingly released into the soil, water and atmosphere $[4,5]$. There is a wealth of evidences that vanadate is absorbed by plant tissues $[6,7]$ and can inhibit the plasma membrane hydrogen $\left(\mathrm{H}^{+}\right)$-translocation ATPase [8], which is known to play an important role in nutrient element uptake by plant cells. 
Vachirapatama et al. [9] revealed that some phosphate fertilizers have been contaminated with high concentrations of $\mathrm{V}\left(90-180 \mathrm{mgkg}^{-1}\right)$. This may suggest that the use of these phosphate fertilizers may cause the $\mathrm{V}$ to become widely spread in soils, water and vegetables and it has potential effects to human and animal health.

According to Kabata-Pendias [10] phytotoxic level of $V$ in plants is $5-10 \mathrm{mgkg}^{-1}$.

The accumulation of $\mathrm{V}$ in plant tissue depends on plant species and $\mathrm{V}$ content in soil [11].

There are no data in the literature on $\mathrm{V}$ content in the Skadar Lake ecosystem.

Our research aims to find the $V$ content per fractions of sediments, and estimate bioavailability, by analyzing content ratios in the sediment, water and macrophytes as well as plant tissue distribution, which can indicate possible absorption or distribution mechanisms and ability to bioaccumulate $\mathrm{V}$.

The aquatic macrophytes used as indicator species in this study Phragmites australis (Cav.) Trin. ex Steud. and Ceratophyllum demersum L. were taken from six locations around Lake Skadar, from early April to late October, every 60 to 70 days. Samples of L. minor were collected in two time periods, in August and October, from four separate locations. Water and sediment samples were also taken from the same time and from the same locations as where the plant material was taken.

\section{EXPERIMENTAL}

\subsection{Study area}

Skadar Lake is the largest freshwater lake in the Balkan Peninsula. It is located at a distance of about $7 \mathrm{~km}$ from the Adriatic Sea. Depending on the amount of water within it, the surface of the lake varies from 379 to $530 \mathrm{~km}^{2}$. Skadar Lake has been a National Park since 1983 and has had IBA status (area of international importance for birds) since 1989. In 1995 it was included on the List of Wetlands of International Importance -The Ramsar List.

Sediment samples from Lake Skadar were collected at 6 locations: 1-Raduš $\left(42^{\circ} 13^{\prime} 26,85^{\prime \prime} \mathrm{N}\right.$; $\left.19^{\circ} 09^{\prime} 54,44^{\prime \prime} \mathrm{E}\right), 2$ - left estuary of the Morača $\left(42^{\circ}\right.$ $\left.15^{\prime} 55,80^{\prime \prime} \mathrm{N} ; 19^{\circ} 08^{\prime} 31,49^{\prime \prime} \mathrm{E}\right)$, 3- right estuary of Morača $\left(42^{\circ} 16^{\prime} 50,18^{\prime \prime} \mathrm{N} ; 1^{\circ} 07^{\prime} 38,92^{\prime \prime} \mathrm{E}\right)$, 4Plavnica (42 $\left.16^{\prime} 17,48^{\prime \prime} \mathrm{N} ; 19^{\circ} 12^{\prime} 1,01^{\prime \prime} \mathrm{E}\right), 5$ - Crni Žar (42 $17^{\prime} 49,30^{\prime \prime} \mathrm{N} ; 19^{\circ} 22^{\prime} 23,75^{\prime \prime}$ E) i 6- Rijeka Crnojevića ( $\left.42^{\circ} 21^{\prime} 6,03^{\prime \prime} \mathrm{N} ; 19^{\circ} 02^{\prime} 23,05^{\prime \prime} \mathrm{E}\right)$.

\subsection{Sampling collection}

Samples of $P$. australis and $C$. demersum were collected four times during the season, from the beginning of April to the end of October, from six locations. Samples of sediment and water were taken at the same time and place, where the plant material was taken.

Sediment sampling was conducted using an Eckman dredge to a depth of $0-20 \mathrm{~cm}$. The sediment samples were placed in plastic boxes, carefully labeled and transferred to the laboratory for further analysis.

Water samples at $50-100 \mathrm{~cm}$ depth below water surface were collected in triplicates and combined as composite water samples at each sampling site. They were kept at $4^{\circ} \mathrm{C}$ and directly transferred to the laboratory. Water samples were filtered through a Millipore filter $0.45 \mu \mathrm{m}$ and stored in plastic bottles of $1 \mathrm{~L}$ by adding $2 \mathrm{~mL}$ of $\mathrm{HNO}_{3}$. Nitric acid was added into water samples to adjust water $\mathrm{pH}$ and stabilize metals.

\subsection{Preparation of samples for chemical analysis}

\subsubsection{Macrophytes}

Sampled plant material in the laboratory was first washed with tap water, and then twice with deionized water. The plant parts (roots, stems and leaves of macrophytes) were cut with stainless scissors, to determine bioaccumulation diversity of plant organs. The plant material was then dried at $75^{\circ} \mathrm{C}$ for 48 hours, and then ground into fine powder and homogenized. In order to avoid the influence of matrix the samples were mineralized. The amount of approximately $0.5 \mathrm{~g}( \pm 0.0001 \mathrm{~g})$ of the prepared samples was measured and mineralized into the Milestone Microwave Ethos 1, with the mixture of $\mathrm{HNO}_{3}$ and $\mathrm{H}_{2} \mathrm{O}_{2}(5 \mathrm{ml}: 2 \mathrm{ml})$. After digestion the solutions were diluted by deionized water to the final volume of $50.0 \mathrm{~mL}$.

\subsubsection{Sediment}

Sediment samples were dried in air, and in a dryer at the temperature of $75^{\circ} \mathrm{C}$ for 48 hours. Dried sediment samples were ground in agate mortar and sieved through a sieve $<1.5 \mathrm{~mm}$. Approximately $0.5 \mathrm{~g}( \pm 0.0001 \mathrm{~g})$ of the sample sediment under pressure and high temperature was mineralized with the mixture of $\mathrm{HCl}: \mathrm{HNO}_{3}$ (3:1) in a microwave furnace, a Milestone Microwave Ethos 1 [12]. After mineralization solutions were diluted with deionized water to the final volume of $50.0 \mathrm{~mL}$.

All samples of plants parts, sediments and water were prepared for three times and their average value was analyzed. In each batch of ten samples blank solution was measured. Determining the concentration of $V$ in the samples of waters, sediments and plants was conducted by ICP-OES technique on a "Spectro Arcos" device.

In our study, vanadium from the sediments of Lake Skadar (Montenegro) was extracted with five 
different extracts: exchangeable-cation $\left(\mathrm{NH}_{4} \mathrm{Cl}\right.$, $\mathrm{CaCl}_{2}, \mathrm{CH}_{3} \mathrm{COONa}$ ), organic acid (oxalic acid) and complexing reagent (EDTA). These extracts represent real environmental conditions, so the aim of this study was to determine the proportion of mobile and mobilizable metals in sediments and predict their bioavailability.

In order to determine the distribution of the $\mathrm{V}$ in the sediment we applied a modified BCR (the Community Bureau of Reference of the European Union) sequential extraction procedure of the sample sediment [13].

The Enrichment Ratio (ER), Geo-accumulation index (Geol) Contamination Factor, CF, and Risk Assessment Code (RAC), have all been calculated to assess whether the observed concentrations of $\mathrm{V}$ in sediment represent background/natural or anthropogenic contamination.

Enrichment factor of $\mathrm{V}$ was calculated as the ratio of $\mathrm{V}$ concentration of sediment normalized to immobile $\mathrm{Fe}$ [14]: $\mathrm{EF}=(\mathrm{V} / \mathrm{Fe})_{\text {sediment }} /(\mathrm{V} / \mathrm{Fe})_{\text {reference. }}$.

The geoaccumulation index (Geol), defined by Müller [15] was calculated as follows: Geol= $\log _{2}\left[C_{V} / 1.5 B_{V}\right]$, where $C_{V}$ is the concentration of $V$ in the sediment and $B_{V}$ is the geochemical background value for $\mathrm{V}$. The factor 1.5 is incorporated in the relation ship to account for possible variations in the background data due to the lithogenic effect [15].

Contamination factor of sampling sites defined by Håkanson [16] was determined as: $\mathrm{CF}=\mathrm{C}_{V}$ Imean $\mathrm{B}_{\mathrm{V}}$

Table 1. Seasonal minimum and maximum vanadium concentrations and mean concentration \pm standard deviation; in water $\left(\mathrm{mg} \mathrm{dm}^{-3}\right)$ and sediment $\left(\mathrm{mg} \mathrm{kg}^{-1}\right)$

Tabela 1. Sezonske minimalne i maksimalne koncentracije vanadijuma i srednja koncentracija \pm standardna devijacija; $u$ vodi $\left(\mathrm{mg} \mathrm{dm}^{-3}\right)$ i sedimentu $\left(m g \mathrm{~kg}^{-1}\right)$

\begin{tabular}{|c|c|c|c|c|c|}
\hline Medium & & April & June & August & October \\
\hline \multirow{2}{*}{ Water } & min-max & $0.002-0.007$ & $0.002-0.007$ & $0.002-0.006$ & $0.002-0.005$ \\
& mean \pm s.d. & $0.004 \pm 0.002$ & $0.004 \pm 0.002$ & $0.004 \pm 0.002$ & $0.004 \pm 0.001$ \\
\hline \multirow{2}{*}{ Sediment } & min-max & $20.4-46.7$ & $20.1-45.3$ & $18.8-49.5$ & $18.1-45.5$ \\
& mean \pm s.d. & $29.4 \pm 9.93$ & $28.9 \pm 10.6$ & $27.9 \pm 11.7$ & $26.9 \pm 9.92$ \\
\hline
\end{tabular}

Table 2 shows average values of the total and the extracted content of vanadium (minimum and maximum values and average value) in the sediment for five different extraction agents.

Table 2. Minimum and maximum value and mean value of total vanadium content $\left(\mathrm{mgkg}^{-1}\right)$ and vanadium concentration $\left(\mathrm{mgkg}^{-1}\right)$ extracted from sediments by different extraction agents

Tabela 2. Minimalna i maksimalna vrijednost i srednja vrijednost ukupnog sadržaja vanadijuma $\left(m k^{-1}{ }^{-1}\right) i$ koncentracija vanadijuma $\left(\mathrm{mgkg}^{-1}\right)$ ekstrahovanog iz sedimenata različitim ekstrakcionim sredstvima

\begin{tabular}{|l|c|c|c|c|c|c|}
\hline & $\begin{array}{c}\text { Total content } \\
\text { of } \mathrm{V}\end{array}$ & $\begin{array}{c}0.1 \mathrm{M} \mathrm{NH}_{4} \mathrm{Cl} \\
\mathrm{pH} 9\end{array}$ & $\begin{array}{c}0.1 \mathrm{M} \mathrm{CaCl}_{2} \\
\mathrm{pH} 7\end{array}$ & $\begin{array}{c}0.1 \mathrm{M} \mathrm{Na} \text {-acetate } \\
\mathrm{pH} 9\end{array}$ & $\begin{array}{c}0.1 \mathrm{M} \mathrm{H}_{2} \mathrm{C}_{2} \mathrm{O}_{4} \\
\mathrm{pH} 2\end{array}$ & $\begin{array}{c}0.1 \mathrm{M} \text { EDTA } \\
\mathrm{pH} 7\end{array}$ \\
\hline min-max & $18.1-49.5$ & $0-0.29$ & $\mathrm{nd}$ & $0.11-0.86$ & $6.28-27.1$ & $4.55-19.1$ \\
mean & 28.3 & 0.13 & 0.39 & 12.4 & 7.48 \\
\hline
\end{tabular}


The mean values of vanadium concentrations $\left(\mathrm{mgkg}^{-1}\right)$ as a result of sequential extraction of sediments are shown in Table 3.

Table 3. Distribution of vanadium $\left(\mathrm{mgkg}^{-1}\right)$ by sediment fractions of Skadar Lake. Fraction: I-Exchangeable and easily mobile; II-Reducable; III-Oxidable; IV-Residual

Tabela 3. Raspodjela vanadijuma $\left(\mathrm{mgkg}^{-1}\right)$ po frakcijama sedimenata Skadarskog jezera. Frakcije: I-Izmjenjiva i lako mobilna; II-Reduktabilna; III-Oksidabilna; IV-Rezidualna

\begin{tabular}{|l|c|c|c|c|c|}
\hline Metal & Fraction $\rightarrow$ & I & II & III & IV \\
\hline $\mathrm{V}$ & min-max & $0.18-0.92$ & $2.77-9.41$ & $3.69-27.1$ & $8.25-17.7$ \\
& mean & 0.67 & 5.37 & 9.32 & 11.8 \\
\hline
\end{tabular}

\subsection{Contents of vanadium in water and sediment} of Skadar Lake

During the research period there were no seasonal variations of mean values of vanadium concentrations in the waters of Skadar Lake, at a confidence level of $95 \%$. There are significant spatial variations of the results, which are reflected in high standard deviation and coefficient of variation, sometimes over $50 \%$. Low content of vanadium was recorded in the water.There are differences between minimum and maximum values of $\mathrm{V}$. The highest content of $V$ in water was recorded on Plavnica and the lowest on the left bank of the Morača River.

During the research period (April-October), statistically significant time variations of vanadium concentrations in the sediment have not been recorded, but they were spatial. The vanadium content varied in sediments of Skadar Lake, within six investigated locations, from 18.1 to $49.5 \mathrm{mgkg}^{-1}$, and the average value was $28.3 \mathrm{mgkg}^{-1}$ (Table 1). The largest content of $\mathrm{V}$ was found at the sites of Crni Žar and Rijeka Crnojevića, while in other places its content was relatively uniform.

Various extracted amounts of vanadium with five different extractants indicated the complexity and variability of $\mathrm{V}$ bond strengths with sediment substrates, and difficulties in defining the proportion of available, mobile or mobilizable metal. The order of solvents with a decreasing amount of extracted vanadium, relative to the total content, was: $\mathrm{H}_{2} \mathrm{C}_{2} \mathrm{O}_{4}(43.8 \%)>\operatorname{EDTA}(26.4 \%)>\mathrm{CH}_{3} \mathrm{COONa}$ $(1.38 \%)>\mathrm{NH}_{4} \mathrm{Cl}(0.46 \%)>\mathrm{CaCl}_{2}(0 \%)$ (Table 2). Extracted amounts of vanadium with less extraction power solvents show that only a small part of $\mathrm{V}$ in the sediments of the Skadar Lake is found in labile, easily accessible form for biota. Acidic conditions $\left(0.1 \mathrm{M} \mathrm{H}_{2} \mathrm{C}_{2} \mathrm{O}_{4}\right)$ showed a higher potential for $\mathrm{V}$ extraction compared to complexing extraction conditions (0.1M EDTA).

The distribution of vanadium by sediment fractions varied within the sampling point, but followed the distribution trend by fractions: IV $>$ III $>$ II $>$ I. The largest amounts of $\mathrm{V}\left(11.8 \mathrm{mgkg}^{-1}\right)$ are incorporated into mineral crystalline lattices (residual fraction), so $\mathrm{V}$ is significantly immobilized metal.In the exchangeable, easily soluble fraction, there were the lowest a quantity of $\mathrm{V}$ in relation to the total, so $V$ is a very weak mobile or low potential mobile element in the sediments of the Skadar Lake. These facts make vanadium, for now, ecologically harmless to the living world of the lake.

Similarly to the sediments of Lake Skadar, Belazi et al. [20] identified that in most sediment samples from the Cumbrian coast, in northwest England, the highest content of vanadium was associated with the residual fraction, while for a smaller number of samples, vanadium is for the most part in the oxidizable fraction. Teng et al. [21] examined the distribution of vanadium across fractions of sediment in different land-use districts in Panzhihua Region, southwest China. They also found the same descending order of content per fractions for vanadium: residual> oxidizable> reducible $>$ acid soluble fraction.

\subsection{Geochemical parameters}

Calculated geochemical parameters are given in Table 4.

The anthropogenic effect expressed through the value of the Enrichment Factor, EF, in the surface sediment of Skadar Lake, showed that vanadium originated only from litogenic sources, without anthropogenic influence.

Based on the value of the Geo-accumulation index, Geol, the sediment in relation to $\mathrm{V}$ belonged to the class "0" in all six sampling locations. This means that the sediment is not contaminated with this metal.

The contamination factor, $\mathrm{CF}$, showed low sediment contamination by vanadium in all sampling locations. Based on the content of vanadium in the acidic soluble fraction of the sediment (Table 4) and the criteria of Risk Assessment Code [17], sediment samples were under the low risk category at all examined locations except for Radus where it has been in the medium risk category. 
Table 4. Geochemical parameters for vanadium by location of sediments of Skadar Lake: Enrichment Factor, EF; Geo-accumulation index, Geol; Contamination factor, CF; Risk Assessment Code, $R A C$

Tabela 4. Geohemijski parametri za vanadijum po lokacijama sedimenata Skadarskog jezera: Faktor obogaćenja, EF; Geo-akumulacioni indeks, Geol; Faktor kontaminacije, CF; Kod procjene rizika, $R A C$

\begin{tabular}{|l|c|c|c|c|c|c|}
\hline Location $\rightarrow$ & Raduš & Plavnica & $\begin{array}{c}\text { Right estuary of } \\
\text { Morača }\end{array}$ & $\begin{array}{c}\text { Left estuary of } \\
\text { Morača }\end{array}$ & $\begin{array}{c}\text { Crni } \\
\text { Žar }\end{array}$ & $\begin{array}{c}\text { Rijeka } \\
\text { Crnojevića }\end{array}$ \\
\hline EF & 0.20 & 0.22 & 0.36 & 0.27 & 0.82 & 0.37 \\
\hline Geol & -3.21 & -3.36 & -2.94 & -3.24 & -2.11 & -2.59 \\
\hline CF & 0.16 & 0.14 & 0.20 & 0.16 & 0.35 & 0.25 \\
\hline RAC & 11.7 & 3.10 & 2.51 & 4.30 & 1.79 & 2.41 \\
\hline
\end{tabular}

\subsection{Time and spatial variation of content of vanadium in macrophytes of Lake Skadar}

Results of vanadium content in individual parts of tested macrophytes and seasons are given in Table 5 .

Table 5. Seasonal changes in vanadium concentrations ( $\mathrm{mgkg}^{-1}$ of dry matter) in particular parts of macrophytes; minimum and maximum value and the mean concentration value \pm standard deviation

Tabela 5. Sezonske promjene koncentracije vanadijuma ( $\mathrm{mgkg}^{-1}$ suve materije) u pojedinim djelovima makrofita ; minimalne i maksimalne vrijednosti i srednja vrijednost \pm standardna devijacija

\begin{tabular}{|c|c|c|c|c|}
\hline \multirow[t]{2}{*}{ Part od plant } & \multicolumn{4}{|c|}{$\begin{array}{l}\text { Minimum and maximum value }\left(\mathrm{mg} \mathrm{kg}^{-1}\right) \\
\text { Mean value } \pm \text { standard deviation }\end{array}$} \\
\hline & April & June & August & October \\
\hline \multicolumn{5}{|c|}{ Phragmites australis $\left({ }^{*}\right)\left({ }^{* *}\right)$} \\
\hline root & $\begin{array}{c}0.29-2.19 \\
1.28 \pm 0.66 \mathbf{a}(\mathbf{c})\end{array}$ & $\begin{array}{c}1.58-4.05 \\
2.62 \pm 0.84 \mathbf{a}(\mathbf{c})\end{array}$ & $\begin{array}{c}6.91-9.24 \\
8.15 \pm 0.95 \text { a (a) }\end{array}$ & $\begin{array}{c}2.66-8.12 \\
4.50 \pm 2.04 \mathbf{a}(\mathbf{b})\end{array}$ \\
\hline stem & $\begin{array}{c}0-0.18 \\
0.12 \pm 0.07 \text { b (b) }\end{array}$ & $\begin{array}{c}0.13-0.32 \\
0.22 \pm 0.07 \mathbf{b}(\mathbf{a b})\end{array}$ & $\begin{array}{c}0.18-0.69 \\
0.30 \pm 0.19 \text { b (a) }\end{array}$ & $\begin{array}{c}0.10-0.23 \\
0.16 \pm 0.04 \mathbf{b} \text { (b) }\end{array}$ \\
\hline leaf & $\begin{array}{c}0-0.20 \\
0.09 \pm 0.07 \text { b (c) }\end{array}$ & $\begin{array}{c}0.15-0.37 \\
0.23 \pm 0.08 \text { b (a) }\end{array}$ & $\begin{array}{c}0.04-0.31 \\
0.15 \pm 0.10 \mathbf{b} \text { (b) }\end{array}$ & $\begin{array}{c}0.02-0.12 \\
0.05 \pm 0.04 \text { b (d) }\end{array}$ \\
\hline \multicolumn{5}{|c|}{ Ceratophyllum demersum $\left(^{* * *}\right)$} \\
\hline stem & $\begin{array}{c}1.89-6.87 \\
3.65 \pm 1.77 \mathrm{ab}\end{array}$ & $\begin{array}{c}0.69-2.28 \\
1.37 \pm 0.64 \mathbf{c d}\end{array}$ & $\begin{array}{c}0.69-2.15 \\
1.25 \pm 0.61 \mathbf{c d}\end{array}$ & $\begin{array}{c}0.34-1.20 \\
0.70 \pm 0.34 \mathbf{d}\end{array}$ \\
\hline leaf & $\begin{array}{c}2.49-8.81 \\
5.42 \pm 2.38 \text { a }\end{array}$ & $\begin{array}{c}0.79-3.95 \\
2.40 \pm 1.14 \text { bcd }\end{array}$ & $\begin{array}{c}1.48-4.95 \\
2.86 \pm 1.15 \text { bc }\end{array}$ & $\begin{array}{c}0.70-2.36 \\
1.56 \pm 0.72 \mathbf{c d}\end{array}$ \\
\hline \multicolumn{5}{|c|}{ Lemna minor } \\
\hline root & & & $\begin{array}{l}1.09-5.57 \\
3.18 \pm 2.18\end{array}$ & $\begin{array}{l}1.58-6.18 \\
4.22 \pm 2.08\end{array}$ \\
\hline leaf & & & $\begin{array}{l}1.58-1.90 \\
1.71 \pm 0.13\end{array}$ & $\begin{array}{l}1.48-5.21 \\
2.78 \pm 1.68\end{array}$ \\
\hline
\end{tabular}

*The values of individual metals with the same first letter(s) are not significantly different at $p=0.05$ in the column (i.e., between the different parts of the plant)

${ }^{* *}$ the values in individual parts of the plant with the sameletter(s) in parentheses are not significantly different at $p=$ 0.05 in the row (i.e., between seasons)

***the values of individual metals with the same letter(s) are not significantly different at $p=0.05$ 


\subsection{Bioaccumulation of vanadium in macrophytes}

Table 6 gives the mean values of Bioconcentration Factor, BCF [(part of plant /sediment (water)] and Translocation ability, TA.

Table 6. Mean annual values of BCF for $V$ in the organs examined macrophytes (part of plant), with respect to sediment (water) and mean annual values translocation ability, TA

Tabela 6. Srednje sezonske vrijednosti BCF za $V$ u ispitivanim djelovima makrofita $u$ odnosu na sediment (vodu) i srednje sezonske vrijednosti translokacione sposobnosti, TA

\begin{tabular}{|c|c|c|c|c|c|}
\hline \multicolumn{6}{|c|}{ Bioconcentration Factor, BCF [(part of plant /sediment (water)] } \\
\hline & & April & June & August & October \\
\hline $\begin{array}{l}\text { Phragmites } \\
\text { australis }\end{array}$ & $\begin{array}{l}\text { root/sediment (water) } \\
\text { stem/sediment (water) } \\
\text { leaf/ sediment (water) }\end{array}$ & $\begin{array}{c}0.05(295) \\
0.004(27.7) \\
0.004(20.8)\end{array}$ & $\begin{array}{c}0.10(395) \\
0.008(55.0) \\
0.01(57.5)\end{array}$ & $\begin{array}{l}0.32(2145) \\
0.01(78.9) \\
0.008(39.5)\end{array}$ & $\begin{array}{l}0.19(1286) \\
0.007(45.7) \\
0.002(14.3)\end{array}$ \\
\hline $\begin{array}{l}\text { Ceratophyllum } \\
\text { demersum }\end{array}$ & $\begin{array}{l}\text { stem/sediment (water) } \\
\text { leaf/ sediment (water) }\end{array}$ & $\begin{array}{c}0.13(842) \\
0.20(1251)\end{array}$ & $\begin{array}{l}0.05(342) \\
0.09(626)\end{array}$ & $\begin{array}{l}0.05(326) \\
0.10(746)\end{array}$ & $\begin{array}{l}0.03(200) \\
0.06(446)\end{array}$ \\
\hline Lemna minor & $\begin{array}{l}\text { root/ sediment (water) } \\
\text { leaf/ sediment (water) }\end{array}$ & & & $\begin{array}{l}0.14(830) \\
0.08(446)\end{array}$ & $\begin{array}{l}0.18(1206) \\
0.12(794)\end{array}$ \\
\hline \multicolumn{6}{|c|}{ Translocation ability, TA } \\
\hline $\begin{array}{l}\text { Phragmites } \\
\text { australis }\end{array}$ & $\begin{array}{l}\text { TA } A_{\text {leaf/root }} \\
\text { TA }_{\text {leaf/stem }} \\
\text { TA }_{\text {stem/root }}\end{array}$ & $\begin{array}{l}0.07 \\
0.75 \\
0.09\end{array}$ & $\begin{array}{l}0.09 \\
1.04 \\
0.08\end{array}$ & $\begin{array}{l}0.02 \\
0.50 \\
0.04\end{array}$ & $\begin{array}{l}0.01 \\
0.31 \\
0.04\end{array}$ \\
\hline $\begin{array}{l}\text { Ceratophyllum } \\
\text { demersum }\end{array}$ & $\mathrm{TA}_{\text {leaf/stem }}$ & 1.48 & 1.75 & 2.29 & 2.23 \\
\hline Lemna minor & $\mathrm{TA}_{\text {leaf/root }}$ & & & 0.54 & 0.66 \\
\hline
\end{tabular}

\section{Phragmites australis}

Vanadium had low bioaccumulation degree during the examined period. The average value during the season (BCF versus sediment) is 0.18 and is almost identical to that given from Bonanno [22]. Generally the entire quantity of accumulated V is found in the underground part of $P$. australis and significantly higher concentration was recorded in August (Table 5). The higher level $\mathrm{V}$ in the root and low mobility indicate that the root is tolerant to this metal. Translocation value $\mathrm{V}$ from root to stem is small and on average is TA $=0.046$. The average ratio of the underground part/leaf is 0.014 . Variations in concentrations during the season in the stems and leaves, as well as of the maximum values during and at the end of the growing season, were noticed.

Ying [23] finds a similar amount of $V$ in tissues of $P$. australis, $1-3 \mathrm{mgkg}^{-1}$, while its concentration in the sediment was 5-33 $\mathrm{mgkg}^{-1}$. He noticed differences in concentration of $\mathrm{V}$ from February to July, with increasing concentration by the appearance of relatively high rainfall. Similarly to this paper, Bonanno [22] determines the presence of $V$ only in the underground organs of $P$. australis, so that the root has acted as an barrier to $\mathrm{V}$ mobility in the above-ground organs. Kabata-Pendias [10] reveals that the soluble forms of $\mathrm{V}$ in the sediment are quickly taken over by the root of the reed. Higher $V$ accumulation in $P$. australis root collected in winter season than that collected in later spring/early summer suggests that $\mathrm{V}$ accumulation in $P$. australis roots is related to the plant seasonal dynamics [11].

\section{Ceratophyllum demersum}

Concentration of $\mathrm{V}$ depended on the season and the sampling point. The average seasonal values in $C$. demersum stem are in the range 0.34 $6.87 \mathrm{mgkg}^{-1}$ (average annual concentration was 1.74 $\left.\mathrm{mgkg}^{-1}\right)$, and in the leaves $0.70-8.81 \mathrm{mgkg}^{-1}$ (average annual concentration was $3.06 \mathrm{mg} \mathrm{kg}^{-1}$ ) (Table 5). The highest concentrations of $\mathrm{V}$ were also observed in the stem and in the leaf of samples of $C$. demersum from the location of Crni Žar. The contents of $\mathrm{V}$ in the stem went down from April to October. Its concentration in the leaf increased up to June, then, during the period of the largest biomass production it is decreasing, and by the end of the vegetative period it increased again.

Bioaccumulation values were different for other authors, from higher, over similar to lower than the results of this paper. Correa et al. [24] observed the highest vanadium concentration in $C$. demersum during the summer $\left(19.5 \mathrm{mgkg}^{-1}\right)$ with a decrease in concentration during the winter $\left(6.1 \mathrm{mgkg}^{-1}\right)$. 
Ravera et al. [25] found that $\mathrm{V}$ in eight macrophytes ranges from 6-27 $\mathrm{mgkg}^{-1}$ with the content in $C$. demersum at $17 \mathrm{mgkg}^{-1}$. Zubcov et al. [26] recorded the content of $\mathrm{V}$ in the range of 0.5-4.4 $\mathrm{mg} \mathrm{kg}^{-1}$, which is less than that found in $P$. australis (0.7-7.1 $\left.\mathrm{mgkg}^{-1}\right)$. Fagbote and Olanipekun [27] found in the dry period during two seasons (2008 and 2009), 0.29 and $0.36 \mathrm{mgkg}^{-1}$ of $\mathrm{V}$; while in the rainy season of the same year, these values were higher: 0.36 and $0.48 \mathrm{mgkg}^{-1}$.

Jiang et. al. [28] reported that $C$. demersum is a candidate for vanadium hyperaccumulator. Particularly since, C. demersum is a native plant species and suitable to the local environment, with a huge potential in phytoremediation for vanadium mining areas.

\section{Lemna minor}

The concentration of vanadium varied considerably following the trend: sediment $>$ root $L$. minor >leaf L. minor > water. Vanadium content in the root, given by seasons as the mean spatial concentration ranged from 1.09 to $6.18 \mathrm{mgkg}^{-1}$ (an average of $3.70 \mathrm{mgkg}^{-1}$ ) and in the leaf from 1.48 to $5.21 \mathrm{mgkg}^{-1}$ (an average of $2.25 \mathrm{mgkg}^{-1}$ ) (Table 5). The highest contents of $\mathrm{V}$ were recorded in the root of $L$. minor, sampled from the location of the left mouth of Morača and in the leaf from the right mouth of Morača. Almost two times higher content of $\mathrm{V}$ was recorded in the organs of $L$. minor at the locations of the mouth of Morača compared to Plavnica and Rijeka Crnojevića. With few exceptions, the $V$ content in the root and leaf of $L$. minor was higher in October than in August. For this plant vanadium has shown a small root-leaf translocation ability (Table 6), but larger than $P$. australis. L. minor also showed a low bioaccumulation capacity for $\mathrm{V}$, but higher than $P$. australis and $C$. demersum.

Piispanen and Lähdesmäki [29] find that at concentration of $10 \mathrm{mg} \mathrm{dm}^{-3} \mathrm{~V}$ is toxic to $L$. minor. Enrichment factor for $L$. minor is 5.0 , which is higher than in terrestrial plants, and the authors suggest $L$. minor for its potential use in geobotanic research. Zubcov et al. [30] in tissues of L. minor (whole plant) from Dubăsari and Cuciurgan reservoir (Moldava), found $0.7-9.2 \mathrm{mgV} \mathrm{kg}^{-1}$ and 4.9-11.3 $\mathrm{mgkg}^{-1}$ of $\mathrm{V}$ respectively.

\subsection{Correlation analysis of metal content in macrophytes and sediment}

Table 7 shows the values of Pearson's correlation coefficient $(r)$ for investigated metals relative to individual parts of the examined macrophytes.

\section{Table 7. Pearson's correlation coefficient, $(p \leq 0.05)$ for $V$ between individual parts of macrophytes}

Tabela 7. Pearsonov korelacioni koeficijent, $(p \leq 0,05)$ za V između pojedinih dijelova makrofita

\begin{tabular}{|c|c|c|c|c|c|}
\hline \multirow{2}{*}{ Metal } & & \multicolumn{2}{|c|}{ Phragmites australis } & $\begin{array}{c}\text { Ceratophyllum } \\
\text { demersum }\end{array}$ & Lemna minor \\
\hline \multirow{2}{*}{$\vee$} & & root & stem & stem & root \\
\hline \multirow{2}{*}{$\mathrm{V}$} & stem & 0.39 & & & 0.42 \\
\cline { 2 - 6 } & leaf & -0.10 & 0.09 & $\mathbf{0 . 9 3}$ & 0.42 \\
\hline
\end{tabular}

$\square \quad$ No correlation

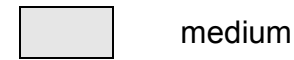

From Table 7, it can be noticed that in $P$. australis, there is significant correlation between examined element content recorded in different plant organs.

On the contrary, there is a very high correlation between the concentrations of $\mathrm{V}$ in the stem and leaf of $C$. demersum.

There was weak correlation between metal content between roots and leaves in $L$. minor. These results indicated the need to determine the content of the metal by individual parts of the plant before the whole plant. Obviously, there is a different translocation of $V$ to certain organs, the amount of adsorbed $\mathrm{V}$ from the water and/or air of the aboveground parts, and the evapotranspiration of aerial parts of the plant.
Table 8 shows the values of Pearson's correlation coefficient $(r)$ between the content $V$ in the surrounding environment (sediment) and individual parts of macrophytes.

The correlation for accumulation of $\mathrm{V}$ between the parts of $L$. minor. was negative and had no statistical significance. The Pearson correlation coefficient between concentrations of $\mathrm{V}$ in sediment and organs of $C$. demersum showed medium correlation in $\mathrm{V}$ stem accumulation in April and October and high correlation in leaf in August. The correlations in $P$. australis accumulation of $\mathrm{V}$ and sediment were medium in root in August and in stem in April. 
These results showed that macrophytes have special and different ways to intake $V$ from the surrounding environment. Gupta and Sinha [31] reported that the process of metal uptake and accumulation by different plants depends on the concentration of available metal's fraction in sediments, solubility sequences and plant species.

Table 8. Correlation coefficients, $(p \leq 0.05)$ between vanadium content in sediment and individual parts of macrophyte

Tabela 8. Korelacioni koeficijenti, $(p \leq 0,05)$ između sadržaja vanadijuma u sedimentu $i$ pojedinim djelovima makrofita

\begin{tabular}{|c|c|c|c|c|c|c|c|c|}
\hline \multirow{2}{*}{ Medium } & & \multicolumn{3}{|c|}{ Phragmites australis } & \multicolumn{2}{c|}{$\begin{array}{c}\text { Ceratophyllum } \\
\text { demersum }\end{array}$} & \multicolumn{2}{c|}{ Lemna minor } \\
\hline \multirow{3}{*}{ Sediment } & Month $\downarrow$ & root & stem & leaf & stem & leaf & root & leaf \\
\hline & $\mathrm{IV}$ & -0.29 & $\mathbf{0 . 6 1}$ & -0.22 & $\mathbf{0 . 6 4}$ & 0.38 & & \\
\cline { 2 - 10 } & $\mathrm{VI}$ & 0.05 & 0.45 & -0.69 & 0.48 & 0.18 & & \\
\cline { 2 - 10 } & $\mathrm{VIII}$ & $\mathbf{0 . 5 2}$ & 0.09 & -0.76 & 0.34 & $\mathbf{0 . 8 5}$ & -0.31 & -0.42 \\
\cline { 2 - 10 } & $\mathrm{X}$ & -0.32 & 0.13 & -0.38 & $\mathbf{0 . 5 3}$ & 0.38 & -0.24 & 0.08 \\
\hline
\end{tabular}

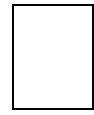

No correlation

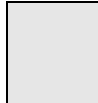

medium

\section{CONCLUSION}

In the sediment of Skadar Lake values of $\mathrm{V}$ were found in the range of 18.1 to $49.5 \mathrm{mgkg}^{-1}$. The distribution of $\mathrm{V}$ by sediment fractions varies with the sampling point, but follows the distribution trend by fractions: residual $>$ oxidable $>$ reductabile $>$ removable and easy mobile. The largest amounts of $\mathrm{V}\left(11.8 \mathrm{mgkg}^{-1}\right)$ are incorporated into mineral crystalline lattices (residual fraction), so $\mathrm{V}$ is considerably immobilized metal in the sediment of the lake. In the exchangeable, easily soluble fraction, there are at least a quantity of $\mathrm{V}$ in relation to the total, so $V$ is a very weak mobile or low potential mobile in the sediments of the Skadar Lake. These facts make $V$, for now, ecologically harmless to the living world on the lake.

Various extracted amounts of vanadium with five different extraction solutions indicate the complexity and variability of $\mathrm{V}$ bond strength with sediment substrates. Extracted amounts of vanadium with less extraction power solvents show that only a small part of $\mathrm{V}$ in the sediments of the Skadar Lake is found in labile, easily accessible form for biota. Acid conditions $\left(0.1 \mathrm{M} \mathrm{H}_{2} \mathrm{C}_{2} \mathrm{O}_{4}\right)$ showed a higher extraction potential of $\mathrm{V}$ compared to complexing extraction conditions (0.1M EDTA). The biodegradable amounts of $V$ from the exchangeable and larger part of the organic (oxidable) fraction.

Based on the calculated geochemical parameters, it can be concluded that the sediment of

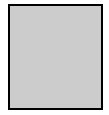

high

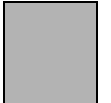

very high

correlation

Skadar Lake is not contaminated with $V$ and it is under the low risk category at all investigated locations.

Mean annual values of vanadium content $(\mathrm{mg}$ $\mathrm{kg}^{-1}$ ), i.e. the average values by time and space for the research season, in some organs of the examined macrophytes is:

\begin{tabular}{|l|l|l|l|l|l|l|l|}
\hline \multirow{3}{*}{ Metal } & \multicolumn{3}{|c|}{$\begin{array}{c}\text { Phragmites } \\
\text { australis }\end{array}$} & \multicolumn{2}{c|}{$\begin{array}{c}\text { Ceratophyllum } \\
\text { demersum }\end{array}$} & \multicolumn{2}{c|}{$\begin{array}{c}\text { Lemna } \\
\text { minor }\end{array}$} \\
\cline { 2 - 9 } & root & stem & leaf & stem & leaf & stem & leaf \\
\hline $\mathrm{V}$ & 4.14 & 0.20 & 0.13 & 1.74 & 3.06 & 3.7 & 2.25 \\
\hline
\end{tabular}

Almost the entire amount of $\mathrm{V}$ during the investigated seasons was accumulated in the root of $P$. australis. Vanadium content in tissues of $C$. demersum decreases at the beginning of the growth season, then increases to the end of the growth season and decreases again until the end of the vegetative cycle. The concentration of $\mathrm{V}$ in the roots and in the leaf of $L$. minor at all locations was higher in October than in August.

In $L$. minor there was a higher content of $\mathrm{V}$ in the root, but unlike $P$. australis, a significant portion is translocated to the leaf. The opposite trend was registered for $C$. demersum, the greater content of $V$ was in the leaf compared to the stem, mainly as a result of translocation. Bioconcentration ability of macrophytes for $V$ was highest in $L$. minor, while $P$. australis and $C$. demersum were identical regarding the same parameter. 


\section{REFERENCES}

[1] V.Kastratović (2018) The water and sediment chemistry of Lake Skadar. In: Pešić V, Karaman GS, Kostianoy AG (eds) The Skadar/Shkodra lake environment. Springer, Berlin, Heidelberg, p.121140.

[2] J.Bartram, R.Balance (2001) Water quality monitoring-a practical guide to the design and implementation of freshwater quality studies and monitoring programmes: Published on behalf of UNEP and WHO, Chapter 2. London Spon Press.

[3] A.Kabata-Pendias, A.B.Mukherjee (2007) Trace Elements from Soil to Human. Springer, Berlin, Heidelberg.

[4] U.Ringelband, O.Hehl (2000) Kinetics of vanadium bioaccumulation by the brackish water hydroid Cordylophoracaspia (Pallas), Bulletin of Environmental Contamination and Toxicology, 65, 486-493.

[5] N.Vachirapatama, Y.Jirakiattikul, G.Dicinoski, A.T.Townsend, P.R.Haddad (2011) Effect of vanadium on plant growth and its accumulation in plant tissues, Songklanakarin Journal of Science and Technology, 33 (3), 255-261.

[6] B.J.Bowman (1983) Vanadate uptake in Neurospora crassa occurs via phosphate transport system II, Journal of Bacteriology, 153, 286-291.

[7] C.I.Ullrich-Eberius, A.Sanz, A.J.Novacky (1989) Evaluation of arsenate and vanadate associated changes of electrical membrane potential and phosphate transport in Lemma Gibba G1, Journal of Experimental Botany, 40, 119-128.

[8] F.Vara, R.Serrano (1982) Partial purification and properties of the proton-translocating ATPase of plant plasma membranes, Journal of Biological Chemistry, 257, 12826-12830.

[9] N.Vachirapatama, G.Dicinoski, A.T.Townsend, P.R.Haddad (2002) Determination of vanadium as PAR-hydrogen peroxide complex in fertilisers by ion-interaction RP-HPLC, Journal of Chromatography A, 956, 221- 227.

[10] A.Kabata-Pendias (2001) Trace Elements in Soils and Plantts, Third Edition, CRC Press, USA.

[11] Y.Qian, F.J.Gallagher, H.Feng, M.Wu, Q.Zhu (2014) Vanadium uptake and translocation in dominant plant species on an urban coastal brownfield site, Science of the Total Environment, (476-477), 696704.

[12] USEPA Method 3051a. (2007) Microwave assisted acid digestion of sediments, sludges, soils and oils, Revision 1.

[13] M.Pueyo, J.Sastre,E.Hernandez, M.Vidal J.F.Lopez-Sanchez, G.Rauret (2003) Prediction of trace element mobility in contaminated soils by sequential extraction, Journal of Environmental Quality, 32(6), 2054-2066.
[14] S.A.Simex, G.R.Helz (1981) Regional geochemistry of trace elements in Chesapeake Bay, Environmental Geology, 3, 315-323.

[15] G.Müller (1979) Schwermetalle in den Sediment des Rheins. VeranderungenSeit 79, 778-783

[16] L.Håkanson (1980) An ecological risk index for aquatic pollution control-a sedimentological approach, Water Research, 14, 975-1001.

[17] G.Perin, L.Craboledda, M.Lucchese, R.Cirillo L.Dotta, M.L.Zanetta, A.A.Oro (1985) Heavy metal speciation in the sediments of northern Adriatic Sea. A new approach for environmental toxicity determination. In T. D. Lakkas(Ed.), Heavy metals in the environment (Vol. 2). Edinburgh:CEP Consultants.

[18] D.Hawker, D.Connell (1991) An evaluation between bioconcentration factor and aqueous solubility, Chemosphere, 23, 231-241.

[19] H.Deng, Z.H.Ye, M.H.Wong (2004) Accumulation of lead, zinc, copper and cadmium by wetland plant species thriving in metal-contaminated sites in China, Environmental Pollution, 132, 29-40.

[20] A.U.Belazi, C.M.Davidson, G.E.Keating, D.Littlejohn, M.McCartney (1995) Determination and speciation of heavy metals in sediments from the Cumbrian coast, NW England, UK, Journal of Analytical Atomic Spectrometry, 10, 233-240.

[21] Y.Teng, J.Yang, Z.Sun, J.Wang, R.Zuo, J.Zheng (2011) Environmental vanadium distribution, mobility and bioaccumulation in different land-use Districts in Panzhihua Region, SW China, Environmental Monitoring and Assessment, 176(1), 605-620.

[22] G.Bonanno (2011) Trace element accumulation and distribution in the organs of Phragmites australis (common reed) and biomonitoring applications, Ecotoxicology and Environmental Safety, 74, 10571064.

[23] M.Ying (2005) Monitoring of Heavy Metals in the Bottelary River Using Typha capensis and Phragmites australis. MSc Mini-thesis, Department of Biodiversity and Conservation Biology,University of the Western Cape.

[24] M.R.Correa, E.D.Velini, D.P.Arruda (2002) Teores de metais na biomassa de Egeria densa, Egeria najas e Ceratophyllum demersum, Planta daninha, $20,45-49$.

[25] O.Ravera, R.Cenci, G.M.Beone, M.Dantas and P.Lodigiani (2003) Trace element concentrations in freshwater mussels and macrophytes as related to those in their environment, Journal of Limnology, 62(1), 61-70

[26] E.Zubcov, N.Zubcov, A.Ene, N.Bagrin, L.Biletchi (2010) The Dynamics of Trace Elements in Dniester River, Journal of Science and Arts Year, 10(2), 281286. 
[27] O.E.Fagbote, E.O.Olanipekun (2013) Evaluation of the Status of Heavy Metal Pollution of Water (Surface and Ground) and Aquatic Macrophyte (Ceratophyllum demersum) of Agbabu Bitumen Deposit Area, Nigeria, British Journal of Applied Science \& Technology, 3(2), 289-306.

[28] B.Jiang, Y.Xing, B.Zhang, R.Cai, D.Zhang, G.Sun (2018) Effective phytoremediation of low-level heavy metals by native macrophytes in a vanadium mining area, China, Environmental Science and Pollution Research, 25, 31272-31282.
[29] R.Piispanen, P.Lähdesmäki (1983) Effect of vanadium on some water plants, Geologiska Föreningen i Stockholm Förhandlingar, 105(1), 2327.

[30] E.Zubcov, L.Biletchi, N.Zubcov, E.Philipenko, N.Borodin (2013) Metal accumulation in aquatic plants of Dubăsari and Cuciurgan reservoirs MuzeulOlteniei Craiova, Oltenia, Studiiúicomunicări, StiinteleNaturii, Tom. 29, No. 2/2013

[31] A.K.Gupta, S.Sinha (2007) Phytoextraction capacity of the plants growing on tannery sludge dumping sites, Bioresource Technology, 98, 1788-1794.

\section{IZVOD}

\section{USVAJANJE, TRANSLOKACIJA I BIOAKUMULACIJA VANADIJUMA U EKOSISTEMU SKADARSKOG JEZERA, CRNA GORA}

Skadarsko jezero je visoko ranjivi ekosistem pogođen različitim vrstama antropogenih pritisaka. Poslednjih nekoliko godina, interesovanje za vanadijumom (V) je poraslo zbog nekoliko negativnih uticaja na životnu sredinu. Naše istraživanje ima za cilj da odredi sadržaj $V$ po frakcijama sedimenta i procijeni njegovu bioraspoloživost, uključujući analizu odnosa sadržaja u sedimentu, vodi i makrofitima i raspodjeli u biljnim tkivima. Zabilježen je nizak sadržaj vanadijuma u vodi. $U$ sedimentu Skadarskog jezera nađene vrijednosti su u opsegu od 18.1 do $49.5 \mathrm{mg} \mathrm{kg}^{-1}$. Najveće količine $V\left(11.8 \mathrm{mg} \mathrm{kg}^{-1}\right)$ nalaze se u kristalnim rešetkama minerala (rezidualna frakcija), tako da je $V$ znatno imobilisan u sedimentu jezera. Na osnovu izračunatih geohemijskih parametara može se zaključiti da sediment Skadarskog jezera nije zagađen $V i$ da je pod niskim rizikom na svim istraživanim lokacijama. U tkivima ispitivanih makrofita srednja vrednost sadržaja $\mathrm{V}$, u odnosu na lokaciju i vrijeme uzorkovanja, je u opsegu $0.05-8.15 \mathrm{mg} \mathrm{kg}^{-1}$ suvog dijela biljke. Proučavane makrofite su pokazale nizak kapacitet bioakumulacije za V. Zabilježen je različit sezonski trend koncentracije $V$ u makrofitima. I translokaciona sposobnost između pojedinih dijelova biljaka je različita i zavisi od vrste makrofita.

Ključne riječi: Skadarsko jezero, sediment, makrofite, vanadijum, bioindikator.

\section{Naučni rad}

Rad primljen: 07. 09. 2019.

Rad prihvaćen: 22. 11. 2019.

Rad je dostupan na sajtu: www.idk.org.rs/casopis

(C) 2020 Authors. Published by Engineering Society for Corrosion. This article is an open access article distributed under the terms and conditions of the Creative Commons Attribution 4.0 International license (https://creativecommons.org/licenses/by/4.0/) 